Volume 2 Issue 2, September 2017: pp. 1-10. Copyright @ LamLaj. Faculty of Law, Lambung Mangkurat University, Banjarmasin, South Kalimantan, Indonesia. ISSN: 2502-3136 | e-ISSN: 2502-3128. Open Access at: http://lamlaj.ulm.ac.id/web/

\title{
POSITION OFFENSES BY NOTARY IN MAKING AUTHENTIC DEED: REVIEWING THE NOTARY RESPONSIBILITY
}

\author{
Santi Rosiana Lestari ${ }^{1}$, Ichsan Anwary ${ }^{2}$, Mispansyah ${ }^{3}$ \\ Program Magister Kenotariatan Fakultas Hukum Universitas Lambung Mangkurat. \\ Jl.Brigjend H. Hasan Basri Komplek Banjarmasin 70123 Indonesia \\ Fax: $05113307877+$ E-mail : santirosianalestari@gmail.com \\ Fakultas Hukum Universitas Lambung Mangkurat. \\ Jl.Brigjend H. Hasan Basri Komplek Banjarmasin 70123 Indonesia \\ Fax:05113307877+E-mail : sanwary2106@gmail.com \\ Fakultas Hukum Universitas Lambung Mangkurat. \\ Jl.Brigjend H. Hasan Basri Komplek Banjarmasin 70123 Indonesia \\ Fax:05113307877+E-mail : ipan.shmh@gmail.com
}

Submitted: 18/09/2017; Reviewed:21/09/2017; Accepted: 30/09/2017

\begin{abstract}
The research aims to analyze the notary' responsibility as common official who conduct contempting of court in making deed and notary'criminal responsibility in running the deed and criminal liability of Notary in conducting its position. The type of research is normative-legal or also called as doctrinal research. The results of research indicate the form of notary' responsibility can be administrative, civil or criminal responsibility. Especially the notary' criminal responsibility is not clearly regulated in the Notary Act, but its responsibility is very dependent on "deliberate" (opzet) in notay' conduct. In making the deed, the notary shall be responsible for the deeds which are made there or which are intentional mistake, on the contrary if the element of mistake occurs from the parties confronting, so as long as the Notary conducitng ith authority in accordance with the laws and regulations, the Notary concerned cannot be requested accountability, since the Notary simply records what the parties are saying to be contained into a deed.
\end{abstract}

Keywords: Notary; Official Offenses; Deed; Responsibility

\section{INTRODUCTION}

Notary is one branch of the oldest legal profession in the world. The position of notary is not placed in legislative, judicial and 
executive institutions. Notary is expected to have a neutral position, so if placed in one of three the institutions it cannot be considered neutral. Notaries as public officials have a central role in upholding the law in Indonesia, because in addition to the very large quantity of a notary, it is known to enter the elite group in Indonesia. ${ }^{1}$

Normatively, the Notary as authorized common official to make an authentic deed is supervised by the Notary Supervisory Council as stipulated in Act No. 30 of 2004 regarding Notary Position (State Gazette of the Republic of Indonesia of 2004 Number 117, Supplement to State Gazette of the Republic of Indonesia Number 4432) as amended by Act No. 2 of 2014 on amendment to Act No. 30 of 2004 regarding Notary Position (State Gazette of the Republic of Indonesia of 2014 Number 3, Supplement to State Gazette of the Republic of Indonesia Number 5491) (hereinafter referred to as UUJN). Previously, the supervision of Notaries was also conducted by the government based on the Supreme Court Circular No. 2 of 1984 regarding Procedure of Notary Supervision as the implementation of Notary Regulation (Staatblad 1860 No. 3 ). Supervision of notary before the enactment of UUJN is done by the local District Court. Then after the enactment of the UUJN, the supervision of the notary is conducted by the Minister that in exercising the supervision, the ministry establishes the Supervisory Board. Membership of the Supervisory Board is 9 peoples consisting of 3 people from the government, 3 people from the notay organization, and 3 peoples of experts/academics. According to article 68 of the UUJN, the No-

1 Abdul Ghofur Anhori. 2009. Lembaga Kenotariatan Indoonesia; Perspektif Hukum dan Etika. Yogyakarta: UII, page. 1. tary Supervisory Assembly shall consist of: a) District Supervisory Board; b) Regional Supervisory Board; and c) Central Supervisory Board.

Notary is a profession of trust and is different from the profession of lawyers, in which Notary in performs his/her office is impartial. Therefore, in his position to the concerned is believed to make evidence that has authentic power. Thus, the rules or laws governing the Notary's position have been so strictly, enforced that they can guarantee the authenticity of the deeds made before him. In performs his/her position, a notary is not sufficient only to have legal expertise but also must be based on the responsibility and appreciation of the nobility of the dignity and nobility of his/her position, because if it is ignored by a notary, it will be dangerous for the general public that served. The role and authority of notary is very important for legal traffic in society, therefore notary must be able to perform profession in a professional, dedicated and always uphold its prestige and dignity by upholding the code of ethics of notary.

In performing a task, whether it is a position or profession duties, each implementation is required accountability of each individual who perform it. Regarding the official responsibility according to Kranenburg and Vegtig, there are 2 (two) underlying theories namely:

1. Theory of fautes personalles, states that the loss to a third party is charged to an official who because of his/her actions has caused a loss. In this theory the burden of responsibility is directed at humans as individuals;

2. Theory of fautes de services, states that losses to third parties are charged to the agency of the official concerned. Accord- 
ing to this theory responsibility is charged to the position. In practice, the losses incurred are also adjusted whether the mistake is serious or minor, where the serious and minor of a mistake implicate to the responsibility to be borne. ${ }^{2}$

Each notary appointed shall pronounce the oath of position as required in article 4 paragraph (2) of UUJN, one of its content is as follows:

"I will maintain my attitude, conduct, and will perform my duties in accordance with the professional code of ethics, honor, dignity, and responsibility as a notary".

It means that the code of ethics of notary profession is a guideline of attitude and behavior of notary. Code of ethics is established by the Notary Organization (Article 83 paragraph [1] UUJN). In performing the duties of his/her position, the notary must adhere to the code of ethics. Code of ethics is a moral norm determined by the association of Ikatan Notaris Indonesia (INI) based on the Congress Decision and/or as determined and stipulated in the laws and regulations governing it and applicable to, and shall be obeyed by any and all members associations and all persons performing the duties and positions of notary. INI as a gathering organization for notaries has a very important role in enforcing the implementation of the professional code of ethics for the notary.

As a notary is a profession that runs a part of state power in the field of private law and has an important role in making an authentic deed that has the power of perfect proof and because the position of notary is a posi-

2 Ridwan H.R. 2006. Hukum Administrasi Negara. Jakarta: Raja Grafindo Persada, page. 365. tion of trust, then a notary must have good behavior. However, as long as some States, those larger or more powerful, were held to a different standard, or, in fact, not held to account at all, it was premature to speak of such a thing. ${ }^{3}$ Good behavior of notary can be obtained based on notary's code of ethics. Thus, the code of ethics regulates the matters which must be obeyed by a notary in performing his/her position and also outside his/her position. The function of professional code of ethics has 3 (three) meanings: 1) as a means of social control; 2) as a deterrent to the interference of other parties; and 3) to prevent conflict misunderstandings. ${ }^{4}$

Notary as a public official appointed by the government and government as the organ of the state to appoint notary not only for the sake of notary itself, but also for the benefit of the wider community. Notary services related to trust between the parties, in which the state gives great trust to notary. Notary is authorized to make an authentic deed to the extent desired or ordered by law which makes notary. The authentic deed is the strongest and most fulfilled evidence instrument has an important role in every legal relationship in people's lives. In various business relationships, activities in banking, land, social activities, etc., the need for authentication in the form of authentic deeds is increasing in line with the growing demand for legal certainty in various economic and social relations at national, regional, global levels.

3 Christopher Stephen. 2012. "International criminal law: wielding the sword of universal criminal justice?" International and Comparative Law Quarterly, 61(1), 55-89.

4 Supriadi. 2006. Etika dan Tanggung Jawab Profesi Hukum di Indonesia. Jakarta: Sinar Grafika, page. 24. 
Notary in performs his/her position relates to individuals, professional organizations, communities and countries. The relationship of notary with the community and the state are regulated in UUJN and other laws and regulations, whereas the relationship of notary and notary organizations is governed by the code of ethics. Notary as a public official must cling not only to legislation only, but also subject to the code of ethics of notary. Notary positions are double track, on the one hand performing the duty of the state as Public Official, while on the other hand the notary is a profession position. Thus, in addition to supporting the implementation of "Good Governance" must also be subject to the principle of professionalism supported by adherence to the code of ethics. ${ }^{5}$

Nowadays there are cases that trick the notary to the court from civil or criminal case and already there are sentenced by court. For example, a breach of position by a notary in performs his/her position make a deed which has been decided by the judge of the High Court of the Banjarmasin in Decision No. 58/PID/ 2015/PT BJM. The decision of this court explains that Notary Nur Fauzan Cholik, S.H., MKn. (hereinafter referred to as the defendant) is declared to have been legally proven and convincingly guilty of committing a criminal act of providing fraud in which to deliberately provide assistance when the crime is committed, in order to benefit themselves or others unlawfully, by using false names or false circumstances, deceitful, or a series of lies, moving others to hand over

5 M. Bola. 2017. "Legal Standing of Customary Land in Indonesia: A Comparative Study of Land Administration Systems". Hasanuddin Law Review, 3(2), 175-190. doi: http://dx.doi. org/10.20956/halrev.v3i2.1132 something, making debts or erasing accounts and imprisonment for 1 year. The problem as follows:

- Initially on March 1, 2014 witness Hairun Nazmi bin Rustam (the late) (in another case) bought a plot of land from witness Maya Saiman located at Jalan Guntung Manggis Guntung Manggis village, Landasan Ulin Banjarbaru subdistrict based on Certificate of Property Number 1191 dated February 6, 1989 in the name of Maya Saiman with an area of $19.972 \mathrm{M}^{2}$;

- Sale and purchase is conducted in front of defendant notary named Nur Fauzan Cholik and made Deed of Sale and Purchase Number 47 of 2014 dated March 1, 2014 with the price agreement included in the deed of sale and purchase of $\mathrm{Rp}$ 400.000.000,-- (four hundred million rupiah), while the actual price agreed is Rp. 65.000,- (sixty five thousand rupiah) permeter with the total amount is $\mathrm{Rp}$ 1.298.180.000,- (one billion two hundred ninety eight million and one hundred eighty thousand rupiah);

- After signing the deed of sale and purchase, witness Hairun Nazmi did not directly make payment to witness Maya Saiman. Then, Diana Putri Agus as the daughter of the witness Maya Saiman conveyed to the defendant so that the Certificate of Property No. 1191 is not reversed first name before witness Hairun Nazmi pay off the payment. On March 3, 2014 by witness Hairun Nazmi, Certificate of Property No. 1191 was used as collateral/ loan extension in BRI with a value of Rp. 1.800.000.000,- the loan application at Bank is also strengthened by a letter from the defendant as a notary;

- Then the land was sold by witnesses Hai- 
run Nazmi and Maya Saiman and Diana Putri Agus who then agreed to seek new buyers and meet witness Ismaun who was interested to buy the land in early December conducted at notary office. At that time, the defendant stated that the Certificate of Property has been reversed from Maya Ismaun to Hairun Nazmi, whereas previously witness Diana Putri Agus asked that the certificate should not be reversed first before the payment of witness Hairun Nazmi finished to witness Maya Saiman;

- On December 8, 2014, a meeting was held at the Notary Office of Nur Fauzan Cholik attended by witnesses Hairun Nazmi and his wife, witness Maya Saiman, Diana Putri Agus, Ismaun witness and her child, witness Gusti Robiansyah and Sarkani witness who were all in the presence of defendant Nur Fauzan Cholik. Afterwards, defendant Nur Fauzan Cholik showed the Certificate of Property No. 11472 on behalf of Hairun Nazmi to all who attended, including witness Ismaun as the buyer and the defendant conveyed to witness Ismaun that the land was not problematic;

- Whereas the defendant knew that the land had become collateral at BRI Branch Pangeran Samudera Banjarmasin. As a result of the defendants' acts, witness Ismaun suffered a loss of Rp. 1.298.180.000,(one billion two hundred ninety eight million one hundred and eighty thousand rupiah) or at least in that amount;

- The act that invalidates the defendant here is where the defendant as a notary who in performing his duties must always remember the oath of position, but it is not done by the defendant and the defen- dant has misused his authority, should the defendant be able to prevent and stop the wrongdoing procedures and violating the laws and regulations) which he knows and is responsible for, but it is not done by the defendant, resulting in a relatively large loss for the victim (Ismaun) and other considerations is that apart from that the Panel of Judges of the High Court assessing and it can be said that there is a conspiracy between the defendant and witness Hairun Nasmi to harm other legal subjects who in this case are witness Ismaun proven in court on December 8, 2014;

- The defendant has facilitated the defendants' office by witnessing Sale and Purchase between the witness Ismaun and Hairun Nasmi on the land object of the Certificate of Property No. 11472, while the land is in a state of guarantee to another party, besides that previously and also held at the defendants' office on December 5 2014, witness Maya Sulaiman, witness Diana Putri Agus and Hairun Nasmi make land agreement in the Certificate of Property No. 11472 will be sold again to other party for Rp. $65.000,-/ \mathrm{m}^{2}$ which eventually became Rp. $57.000,-/ \mathrm{m}^{2}$, then bought by Ismaun, for this case the defendant should be able to prevent it because the land has been placed the guarantee rights to the other party, but the defendant did not do the prevention.

As described above, a notary who commits an act unlawfully in making authentic deed must be responsible for his/her criminal or civil actions. However, one kind of sanction in notary' responsibility is not enough, so it is necessary to cumulate or merge the sanction as a form of notary' responsibility. Thus, 
the responsibility of a notary to his/her deeds may provide assurance of legal certainty to the notary itself and the aggrieved parties. UUJN is only regulates the implementation of civil and administrative sanctions. UUJN and code of ethics of notary does not regulate the responsibility of a notary in criminal manner against the deed he/she made, when proven to be a violation of criminal law.

In UUJN is only regulates the provisions of civil and administrative law sanctions. However, the responsibility of a notary shall be criminally levied if the notary is found guilty of a criminal act. In the event of a criminal offense committed by a notary, the notary may be subject to criminal sanctions based on the Criminal Code.

Furthermore, during the process of examination, the Honorary Council does not provide legal protection, this is because in the UUJN does not clearly regulate the legal protection for the notary in a criminal case, not only in the UUJN also does not regulate the criminal responsibility of a notary from the deed that has been made based on data and information fabricated by the parties. Therefore, there is a vacuum of legal norm in UUJN related to legal protection and responsibility of notary in making deed.

Based on the background above, it is necessary to question the form of responsibility of notary as public official who commits unlawful acts in making authentic deed and criminal responsibility by notary as a public official against the deed made which is indicated by criminal act.

\section{METHOD}

The research used in this study is norma- tive-legal research, ${ }^{6}$ a method used by collecting and analyzing the materials associated with the problems studied. The materials used consist of primary and secondary legal materials. This research is a descriptive analysis, a research characteristic that describes the actual state of offense by the notary in making authentic deeds.

\section{ANALYSIS AND DISCUSSION}

\section{Notary' Responsibility as Public Official who Conducting Unlawful Actions in the Making of an Authentic Deed}

According to the Indonesian General Dictionary, responsibility is defined as the state of being obligated to bear everything. Accordingly, the responsibility in the dictionary is obliged to bear, to bear everything, or to answer and bear the consequences. Responsibility is the human consciousness of his/her behavior or acts, intentional or unintentional. Responsibility also means acting as a manifestation of awareness of their obligations. ${ }^{7}$

In performs his position as a notary, the intended criminal is a criminal act by a notary in his/her capacity as a public official authorized to create or making an authentic deed as mandated by UUJN, so it is not the personal or individual capacity of the notary as a legal subject. The elements of a criminal act include: (a) act (human); (b) comply with the formulation of the law (formal conditions); and (c) unlawful.

In article 1365 of the Civil Code contains the following provisions:

6 Peter Mahmud Marzuki. 2005. Penelitian Hukum. Jakarta: Prenada Media, page. 32.

7 Rizky Adi Wibowo. 2015. Arti Sebuah Rasa Tanggung Jawab. http://www.kompasiana.com/ rizkyadiwibowo/arti-sebuah-rasa-tanggungjawab. Accessed on 10 June 2016. 
"Any act which is unlawful which thereby causes harm to others obliges the person who by his or her fault causes the loss to compensate."

The form of legal responsibility as follows:

a. Responsibility with the element of fault (deliberate and negligent) as it is contained in article 1365 of the Civil Code;

b. Responsibility with the element of fault, especially omissions as contained in article 1366 of the Civil Code, namely: " $\mathrm{ev}$ eryone shall be responsible not only for loss caused by his/her actions but also for harm caused by negligence or lack of care;"

c. Absolute responsibility (without fault) as contained in article 1367 of the Civil Code.

Responsibility in unlawfully acts, there are 2 (two) kinds of responsibilities, namely:

1. Direct responsibility, that is, a person responsibility for losses incurred by the person himself, pursuant to article 1365 of the Civil Code;

2. Indirect responsibility, that is, a person responsibility for loss caused by another person in the course of performing his/her job duties and under the security of the person responsible (Article 1367 Civil Code).

According to E. Utrecht, ${ }^{8}$ that:

"Position (ambt) is a permanent employment environment (kring van vaste werkzaamheden) held and conducted for the benefit of the State (public interest)."

Notary is a public official has characteristics, namely:

1. As position;

8 Ibid,
2. Notary has certain authority;

3. Appointed and dismissed by the government;

4. Not receiving a salary or pension from the one who appoint it; and

5. Accountability for his/her works to the public.

The legal responsibility of a Notary in performs his/her profession according to Lanny Kusumawati is classified in 2 (two) forms, namely:

a. Civil responsibility that is if a notary has committed a mistake by breaking a promise as determined in the provisions of article 1234 of the Civil Code or any unlawful act as defined in the provisions of aArticle 1365 of the Civil Code. Against such fault has caused the loss of the client or other party;

b. Criminal responsibility when a notary has committed a legal act prohibited by law or commits a wrongful/unlawful act either because of intention or negligence which causes the loss of the other party. ${ }^{9}$

Elements of unlawful act include the existence of an act against the law, the existence of fault and loss incurred. In detail the unlawfully act in the broadest sense is if the act is:

a. Violate the other' rights;

b. Contrary to the legal obligations of the perpetrator;

c. Contrary to decency; or

d. Contrary to the propriety in observing the self-interest and property of others in the interaction of everyday life.

Certainly, in this case is a criminal act

9 Lanny Kusumawati. 2006. Tanggung Jawab Jabatan Notaris. Bandung: Refika Aditama, page, 49. 
committed by notary in his/her capacity as a public official authorized to make the deed and not in the context of individuals as citizens in general. The consequence of a criminal offense is criminal responsibility it must meet the element of a criminal offense:

1. In the making of a deed by a notary, if there is an element of fraud or in the process of making a deed by a client and a notary does not know, then the notary cannot be held criminally liable for not fulfilling the principle of mens rea unless the notary is aware of and keep processing the deed. Criminal responsibility can only be sought in the case of a notary who deliberately makes a deed that truly meets the aspects of fraud and forgery;

2. The occurrence of a crime against a notary based on a deed made by or in the presence of a notary as part of the execution of duties or authority of notary, regardless of the rule of law relating to the procedure of making the deed and only under the provisions of the Criminal Code, indicates that there has been a misunderstanding or interpretation of position of notary, while the authentic deeds made by notaries as evidence in civil law. Criminal sanctions are ultimum remedium, if sanctions or attempts at other branches of law are not susceptible or considered to be impervious.

Regarding sanctions imposed on a notary as an individual under Article 85 of the UUJN may be: a) oral warning; b) written warning; c) temporary dismissal; d) respect dismissal; and e) disrespectful dismissal.

According to Abdul Kadir Muhammad, notary in performs his/her duties should be as follows: a. Notary is required to making a deed properly and correctly. This means that the deed made fulfills the legal will and request of the interested parties because of his/her position;

b. Notary is required to produce a quality deed. This means that the deed made in accordance with the rules of law and the will of the parties concerned in the real sense. The notary must explain to the parties concerned the truth of the contents and procedures of the deed he made;

c. Impacted positively, meaning that anyone will recognize the notary deed has perfect proof of power.

Criminal Responsibility by Notary as Public Official against Deed Made and Indicates as a Criminal Act

UUJN does not contain criminal provisions for a notary, so if there is a crime related to the position of notary refers to the Criminal Code or other material criminal law. But that does not mean that a notary is immune from law when committing a violation of the law in performing his/her position. Criminal acts are actions that are contrary to the order desired by law, where the main requirement of a criminal act is the fact that there is a prohibiting rule..$^{10}$

The formulation of the Criminal Code which is closely related to the profession of notary is a criminal act which is closely related to the participation crime (Article 55), helping (Article 56), letter falsification (Article 263 paragraph 1), criminal acts using counterfeit letters or falsified (Article 263 paragraph 2), criminal act of falsifying authentic documents

10 Roeslan Saleh. 1983. Perbuatan Pidana dan Pertanggung Jawaban Pidana. Jakarta: Aksara Baru, page. 9. 
(Article 264 paragraph 1), criminal acts using false or falsified authentic deeds (Article 264 paragraph 2), criminal acts include false information in authentic acts (Article 266 paragraph 1), criminal offenses use false authentic deeds (Article 266 paragraph (2)), secret of office (Article 322 paragraph (1)), embezzlement (Article 372 and Article 374) and falsification by officials (Article 416).

Especially article 322 of the Criminal Code is closely related to several articles in the UUJN, namely the oath of position (Article 4 UUJN) and secret notary' secret with the client (Article 16 paragraph 1 letter e UUJN). In the editorial, there is a redaction that states: that I will keep the contents of the deed and the information obtained in the implementation of my position. While, article 16 paragraph 1 letter e UUJN explains that the notary is obliged to keep everything confidential about the deed he/she made and all information obtained for the making of the deed in accordance with the oath of position, unless otherwise provided by law. The obligation to conceal all things dealing with deeds and other papers is to protect the interests of all parties related to the deed. ${ }^{11}$

Whether or not a person is convicted, or to prove the element of a criminal offense, required evidence and legal evidences consisting of: a) witness testimony; b) expert information: c) letters; d) instructions; and e) the defendants' statement. Furthermore, the Criminal Procedure Code has regulated the evidentiary system in a criminal case with a system of substantiation of the law in a negative manner, which requires that to determine the guilt of a person the defendant must be fulfilled with 2 (two) conditions: first, there

11 Abdul Ghofur Anhori. Op.Cit, page. 41. are at least two valid evidences; second, on the basis of valid evidence, obtained the judges' conviction that the defendant was guilty.

In the criminal proof, the term "no crime without guilt" (geen straf zonder schuld) is used, so to determine the guilt of a person in a crime is absolutely necessary proof. The basis for determining the degree of unlawful elements in a criminal law of notary, in addition to being derived from a criminal law itself may also derive from the provisions of UUJN, the Code of Ethics as well as from the provisions of civil law concerning the validity of a treaty.

Forms of formal and material falsification from a notary deed which can be qualified as a criminal act in connection with articles 263 , 264, 266 jo. article 55 and/or article 56 of the Criminal Code, whether cases of existing court decisions and that have not there is a court decision.

The elements of fraud are:

1. In order to benefiting oneself by unlawfully;

2. The fulfillment of the elements contained in article 56 of the Criminal Code, by deliberately providing such assistance, on or before (so not after) the crime is committed.

3. Move people to surrender things or to provide debt or write off accounts;

4. By using any attempt or fraud (using false names, false dignity, tricks, lies).

According to Wirjono Prodjodikoro it is known that there are 5 (five) classes of crime, namely:

1. Who commits action (plegen, dader);

2. Who encourage to commits action (doen plegen, middelijke dader); 
3. Who participate in action (medeplegen, mededader);

4. Who persuade to commit action (uitlokken, uitlokker);

5. Who assist the action (medeplichtig zijn, medeplichtige).

In a criminal case, a notary can be confronted as defendant, witness and expert. There are several possibilities that may ensnare a notary committing a crime and be held criminally liable as a suspect or a defendant. The possibilities are as follows:

1. The date in the deed is inappropriate with the presence of the parties;

2. The parties are absent but are present;

3. The parties have no signature but are written or signed;

4. The actual deed is not read but it has been read out;

5. The different land area described by the parties;

6. The notary interferes with the terms of the agreement;

7. In the deed stipulated that the parties have paid the full payment of what was agreed upon when it has not been paid or there has been no payment in real terms;

8. The inclusion of a reading of the deed which should be done by a notary himself when in fact it is not;

9. The inclusion of knowing the person who is facing when actually does not know him. ${ }^{12}$

Regarding the participation in committing the crime is described by S.R. Sianturi, who says that giving opportunities, means or information is a way to move a person. It is

12 Habib Adjie. Op.Cit, page. 120. clear that if there is a helper there must be assisted, who is called as the main actor. The relationship between the assistants and the principal actors is assistance. Helping or assistance is determined in conjunction with the occurrence of a crime (first article 56 of the Criminal Code) or precedes the commission of a crime (second article 56 of the Criminal Code). ${ }^{13}$

In essence, this nature violates article 1 paragraph (1) of the Criminal Code, both experiment and inclusion by Pompe are seen as "forms of appearance" of the criminal act. ${ }^{14}$ One can talk about an experiment when one is stuck in a crime. Nevertheless, article 53 of the Indonesian Criminal Code determines in these circumstances, can still be criminalized.

Based on article 55 of the Indonesian Criminal Code, it is criminally charged as a maker of a criminal act (a crime and a violation): ${ }^{15}$ 1) those committing a crime; 2) those encourage to committing criminal acts; 3) those who participate in criminal acts; and 4) those who persuade to commit criminal acts.

Based on the articles of the Criminal Code, participation is divided into 2 (two), namely:

1. Maker (dader) is regulated in article 55 of the Criminal Code. The meaning of dader is derived from the word daad which in Dutch means as a matter of doing or as an action. In criminal law science, it is not unusual to say that a perpetrator has com-

13 S.R. Sianturi. 1996. Asas-Asas Hukum Pidana di Indonesia dan Penerapannya. Jakarta: Alumni Ahaem-Petehaem, page. 363.

14 D.N. Keijzer Schaffmeister dan E. PH. Sutorius. 2007. Hukum Pidana. Bandung: Citra Aditya Bakti, page. 245.

15 Ibid, page. 246. 
mitted a criminal offense or that a maker has committed a crime, but what is commonly said is that a perpetrator has committed a crime. The specimina genius of maker is: ${ }^{16}$

a. commit, which means to completely fulfill all elements of the offense;

b. encourage to commit, which means to move another person, who (for any reason) cannot be subject to a criminal act;

c. participate to commit, which means to agree with others to make plans to commit a criminal act and jointly implement it (cooperation);

d. Persuade, which means, with the assistance of one of the attempts of the limitative mentioned in article 55 paragraph (2) of the Criminal Code, commonly referred to as means of inducement, to persuade another person who is indeed criminally convicted to commit a criminal act.

2. Assistant (medeplichtige)

a. Assistance when the crime is committed

b. Assistance before the crime was committed

The person who deliberately recommends (uitlokker) the elements are:

1. Objective elements:

a. the element of action is to encourage others to commit an action;

b. the way is giving something, promising something, abusing power, abusing dignity/position, violence, threats, misdirection, giving opportunity, giv-

16 D.N. Keijzer Schaffmeister dan E. PH. Sutorius. Op.Cit, page 247 ing means, giving information.

2. Subjective elements

The deliberateness of the advocate maker should be directed to 4 (four) things:

a. aimed at the use of advocacy efforts;

b. aimed at realizing the act of encouraging and its consequences;

c. aimed at others to commit action;

d. aimed at others who are capable of being responsible or punished.

3. In commit an action should use advocacy methods as Article 55 paragraph (1) and (2) of the Criminal Code;

4. The formation of the will of the person who is advised (the executing maker) to commit the offense in accordance with what is advocated is directly caused by the use of advocacy efforts by the advocacy maker;

5. The person who is advocated (the implementing) has committed a criminal act in accordance with the recommended;

6. The person who is advocated is the person who has the ability to be responsible. ${ }^{17}$

In the sphere of notary, we known adagium: "everyone who comes to the notary has rightly said is not proportional to saying the truth, which means a lie or giving false information, it becomes the responsibility concerned (the parties)." Subsequently, the deed of notary as an authentic deed has perfect proof power, so that the party reading the deed should see it as it is and the notary does not need to prove anything on the deed made before or by the notary. Therefore, the other person assessing or declaring the no-

17 Abdul Muqtadir Al-haq. 2011. Deelneming. http:// pembelajaranhukumindonesia. blogspot.co.id, Accessed on 25 July 2016 
tarial deed is incorrect, and then those who assess or declare it must prove their judgment or statements in accordance with applicable legal procedures. ${ }^{18}$

A notary may consciously, deliberately with the party concerned (confronting) to do or assist or order to perform a legal act which he knows as unlawful acts. If this is done, in addition to harming the notary, the parties, and ultimately the person performing the duty of a position as a notary is given a speech as a person who always violates the law. ${ }^{19}$

Based on the construction of the Notarial Law, one of the duties of the notary' position is "to formulate the wishes or actions of the constituents in the form of an authentic deed, with due regard to the applicable law. Then the jurisprudence of the Supreme Court (Supreme Court Decision No. 702 K/Sip/1973, September 5, 1973) states: "Notary functions only record or write down what is desired and put forward by the parties facing the notary. There is no obligation for the notary to investigate materially what is presented by the constituents before the notary." ${ }^{20}$

The responsibility of criminal act assistance as regulated in article 57 of the Criminal Code which states:

1. The maximum punishment for crime, less one third for the helper

2. If the crime can be punished by death or life imprisonment, then the prison sentence shall be fifteen years.

3. Additional sentence for crime and help to

18 Alvi Syahrin. 2010. Notaris Pelaku Tindak Pidana Pasal 266 Ayat (1) Kuhp Jo. Pasal 55 Ayat (1) Ke-1 KUHP. http://alviprofdr.blogspot.co.id. Accessed on 29 July 2016.

19 Habib Adjie. Op.Cit, page. 124.

20 Ibid, commit the crime, just the same.

4. To determine the punishment of the helper is only interested the deliberately act to facilitates by the assistance and its consequences.

\section{Criminal Responsibility of Notary Who Commit Unlawfully Act}

Action by which the criminal law rule is expressed as a prohibited act is called a criminal act which is also called as a delict. According to Hermin Hediati Koeswadji, delict or act that is prohibited by law and is threatened with criminal having the following elements: objective elements that exist outside of human beings can be a prohibited act or behavior and threatened with criminal sanctions such as falsifying letters, perjure.

Further according to its nature or character, these criminal acts are unlawful acts. This act also harms the society, which in the sense of contradicting or inhibiting the implementation of the governance of society that is considered good and fair. But not all actions that are unlawful or harmful to society can be called criminal acts. And vice versa, it cannot be said that only the actions that cause big losses are made criminal acts. ${ }^{21}$

Notary who is proven to commit an act unlawfully in performing his/her profession shall be responsible for his/her actions. The amount of responsibility of the notary in performing his/her profession requires the notary to always be careful in every action. However, as an ordinary person, certainly a notary in performing his/her duties and positions sometimes not escape from faults either by deliberate or because negligence which then can harm others. In the imposition of sanctions against the notary, there are several con-

21 Roeslan Saleh .Op.Cit, page. 13. 
ditions that must be fulfilled namely the act of notary must meet the formulation of the act is prohibited by law, the loss resulting from the act of the notary and the act must be unlawful, both formal and material. Formally, it has been fulfilled because it has fulfilled the formulation in law, but materially must be tested again with code of ethics, UUJN and its amendment.

Disgraceful acts by the public are accountable to the actor, which means that objective reprimand against the action is then passed on to the defendant. ${ }^{22}$ The person committing a criminal act will be punished if he/ she has a guilty. Since it is of no use to account for his/her actions if his own conduct is not unlawful, it is further said that in advance there must be certainty of the existence of a criminal act and for any wrongdoing which resulted in the conviction of the defendant, the defendant shall:23
a. committing a crime;
b. able to responsible;
c. intentionally or negligently;
d. there is no excuse for forgiveness

Authentic deeds can be degraded to power of evidence under-the-hand, even can be cancelled, under the following reasons:

1. Notary in making deed is not authorized;

2. Does not have the relevant public official;

3. Defects in its form; or

4. Since the notary deed is revoked based on a court decision having a permanent legal power.

While the conditions for the criminalization of the notary, at least there are 3 (three) things that must be met, namely: First, there

$22 \quad$ Ibid, page. 78 .

23 Ibid are legal actions from the notary to the formal aspects of the deed intentionally full awareness and conviction and planned, that the deed made in the presence of notary or by notary together to serve as a basis for committing a crime; Second, there is legal action from a notary in making a deed in the presence or by a notary which if measured by UUJN is not in accordance with the UUJN; Third, the act of notary is not appropriate according to the authorized institution to assess the act of a notary, in this case the Notary Supervisory Board.

\section{CONCLUSION}

Forms of responsibility to a notary who commits an unlawfully act in the making of an authentic deed may be liable in the form of sanctions to compensate the injured party for the unlawful acts committed by the notary. Administrative responsibility can be of sanction of oral warning, written warning, and dismissal with respect and disgrace with disrespect as a notary.

Also, notary have to face the sanction in the form of ethical sanction if notary do offense to code of ethics of notary official can even be sentenced to criminal sanction. Especially for criminal sanctions against notaries must be seen in order to perform their duties, and subject to general criminal provisions of the Criminal Code, UUJN. UUJN does not regulate specific criminal acts for notary.

Accountabilities for a notary can be in the form of administrative, civil or criminal. Specifically, the criminal responsibility is not clearly stipulated in the UUJN, but the notary criminal responsibility is heavily dependent on "deliberate" (opzet) in the act of notary. In making authentic deeds, a notary shall be liable in the case of a deed which he or she has 
made a deliberate misconduct or violation by a notary. Conversely, if the element of guilt or violation occurs from the confronting parties, so long as the notary exercises his/her authority according to the rules. The concerned notary cannot be held accountable, since the notary only records what the parties have submitted to the deed. The imposition of a criminal sanction against a notary can be made to the extent that such limitations are violated, which means that in addition to meeting the formulation of the violations contained in the UUJN and the code of ethics must also satisfy the formulation contained in the Criminal Code.

\section{Suggestion}

Should the government reconstruct the regulation in UUJN regarding the absence of any accumulation or incorporation of sanctions as a form of responsibility of a notary, which must regulate the authority and temporer dismissal of notary in the status of suspect or defendant, and as deterrent effect. As for the application of these sanctions will certainly provide more protection and legal certainty for the parties who feel harmed by the illegal act of a notary as well as the police investigators to better cooperate with the Regional Supervisory Board to understand and more thoroughly in conducting an investigation of a violation committed by a notary.

A notary either of himself who exercises authority based on position as stipulated in Acts and notary in the sense of individual must be able to place himself where the rights and obligations must be balanced and follow the rules, norms and values applicable and for a notary and the parties are prevented from any risks that resulted in a notary being criminal cases, the notary and the parties must be prudent, impartial, honest, self-employed, aware of their obligations, full of responsibility and more precise and have good faith in making authentic deeds and comply with applicable legal provisions and are based on morals and ethics. In addition, a notary must have general and juridical knowledge sufficiently to perform his/her duties.

\section{BIBLIOGRAPHY}

Anhori, Abdul Ghofur. 2009. Lembaga Kenotariatan Indoonesia; Perspektif Hukum dan Etika. Yogyakarta: UII.

Adjie, Habib. 2009. Sanksi Perdata dan Administrasi Terhadap Notaris Sebagai Pejabat Publik. Bandung: Refika Aditama.

Adjie, Habib. 2009. Sekilas Dunia Notaris dan PPAT Indonesia. Bandung: Refika Aditama.

Adjie, Habib. 2011. Hukum Notaris Indonesia. Bandung: Refika Aditama.

Syahrin, Alvi. 2010. Notaris Pelaku Tindak Pidana Pasal 266 Ayat (1) Kuhp Jo. Pasal 55 Ayat (1) Ke-1 KUHP. http://alviprofdr.blogspot.co.id, Accessed on 29 July 2016.

Bola, M. 2017. "Legal Standing of Customary Land in Indonesia: A Comparative Study of Land Administration Systems" Hasanuddin Law Review, 3(2), 175-190. doi: http://dx.doi.org/10.20956/halrev. v3i2. 1132

Christopher Stephen. (2012). "International criminal law: wielding the sword of universal criminal justice?" International and Comparative Law Quarterly, 61(1), 55-89.

Schaffmeister, D, N. Keijzer, dan E. PH. Sutorius. 2007. Hukum Pidana. Bandung: Citra Aditya Bakti.

Kusumawati, Lanny. 2006. Tanggung Jawab 
Jabatan Notaris. Bandung: Refika Aditama.

Marzuki, Peter Mahmud. 2005. Penelitian Hukum. Jakarta: Prenada Media.

H.R, Ridwan. 2006. Hukum Administrasi Negara. Jakarta: Raja Grafindo Persada.

Wibowo, Rizky Adi. 2015. Arti Sebuah Rasa Tanggung Jawab. http://www.kompasiana.com/rizkyadiwibowo/arti-sebuahrasa-tanggung-jawab. Accessed on 10 June 2016.

Saleh, Roeslan. 1983. Perbuatan Pidana dan Pertanggung Jawaban Pidana. Jakarta: Aksara Baru.

Sianturi, S.R. 1996. Asas-Asas Hukum Pidana di Indonesia dan Penerapannya. Jakarta: Alumni Ahaem-Petehaem.

Supriadi. 2006. Etika dan Tanggung Jawab Profesi Hukum di Indonesia. Jakarta: Sinar Grafika. 